has established the main facts of the geological story of the Province, but there are many places where the absence of fossils, the metamorphosed character of the rocks and the predominance of volcanic members present problems of correlation. The paper gives the conclusions reached by the author as a result of field work carried out in that region over the last quarter of a century, and is a most useful summary for all who are interested in the Appalachian geology of eastern Canada.

Thirteen papers were presented, and a lively discussion on the origin of granites followed the presentation of a paper entitled "Back to Logan" by H. C. Cooke, in which he briefly reviewed the development of theories of granitization and concluded, in harmony with an early interpretation by Sir William E. Logan, that many bodies in granite in Canada have been thus formed. Problems in the interpretation of age relationships of granites were dealt with in "Extent of Proterozoic Granite Intrusions in the Western Part of the Canadian Shield", by J. F. Henderson, and "The Relation of the Granite and the Seine Series at East Shoal Lake, Ontario", by E. L. Bruce and J. S. Ross. "Recent Data on the Nature and Origin of some Iron Deposits in the Canadian Shield", by E. S. Moore, gave information about Algoma and Labrador, where exploration for iron ore is in progress. "An Occurrence of Boron Minerals at Silver Harbor, Ontario", by T. L. Tanton and Eugene Poitevin, described a vein in which danburite has been found for the first time in Canada. "Radioactive Nodules in Sediments of the Sibley Series, Nipigon, Ontario", by T. L. Tanton, reported the results of a recent study of nodules in the red beds of the Sibley series, which were observed to be lithologically similar to uranium-bearing nodules in the Permian red beds of Devon, England. "Eoeponidella", by R. T. D. Wickenden, described a new genus of foraminifera. A paper of general interest to the members of the Section was "The Geological History of Greater Vancouver", by M. Y. Williams.

Section 5 had a very crowded programme with more than fifty papers listed, and for some sessions the Section split into separate botany, zoology and medical sciences subsections. The address of the president, Dr. E. Gordon Young, of Dalhousie University, was entitled "Canadian Dietary Patterns, 1937-1947", and constituted a survey of work on diets in Canada, particularly with reference to the war years. One session was devoted to a symposium on atomic energy in relation to biology. Contributors to this were an introduction by G. M. Shrum; "Problems of Handling and Measuring Stable Isotopes", by H. G. Thode; "Measurement and Handling of Radioactive Isotopes", by A. J. Ciprianni ; "Precautions for Workers Using Radioactive Isotopes", by G. H. Guest ; "Botanical Problems", by J. W. T. Spinks; and "Radiation Genetics", by C. E. Ford.

It was natural that sessions held in British Columbia would include several papers on salmon and other fish. "Mortality in Pink Salmon" was discussed by A. L. Pritchard; "Fecundity and Mortality in Pacific Salmon" and "Migrations and Spawning of Sockeye Smolt" by R. E. Foerster ; and "Movement of Fundy (Atlantic) Salmon" by A. G. Huntsman. Papers dealing with the butter sole and the lemon sole were read by J. L. Keith Stuart Ketchen, and A. L. Tester spoke on "Catch Limitations for Regulation of the B.C. Herring Industry".

\section{SOLUBILITY OF INDUSTRIAL SILICEOUS DUSTS}

\author{
By DR. P. F. HOLT \\ University of Reading
}

AND

Prof. H. V. A. BRISCOE

Imperial College of Science and Technology, London

$T$ HE theory that/tissue damage in silicosis is caused by silici acid formed by solvent action of the plasma on inhaled particles stimulated the study of the solubility of airborne siliceous dusts and of the materials which give rise to them. The investigation of the/solubility of mineral silicates is complicated by/their peculiar properties. When a powdered gliceous mineral is shaken with water, the solution may contain particles which range from large coloidal particles to simple ions; and different workes have determined the solute gravimetrically afte filtration ${ }^{1}$, gravimetrically after ultracentri. fuging ${ }^{2}$ or colorimetrically as the silicomolybdate complex which is formed both with simple and with more complex colloidal silicic acids. King and McGeorge ${ }^{3}$ consider that the colorimetric method is most likely to give figures representing physiologically active 'solubl э silica'.

A mineral suspension does not reach equilibrium with the liquid phase within a reasonably short time, and a comparison of the solubilities of two substances must normally be made by comparing the quantities of solute after a fixed time. The apparent solubility depends on the temperature, the particle sizs of the dust and on the ratio of dust to solvent". Since the extraction of dust particles in the lung by constantly changing lymph is so complex a process that any true imitation is impossible, investigators have attempted to compare solubilities under simplified fixed conditions, and with simpler solvents. For example, Briscoe and others ${ }^{4}$ investigated the effect of water, Whitehouse ${ }^{5}$ used 1 per cent sodium carbonate solution, Emmons and Wilcox ${ }^{8}$ used plasma, while King and McGeorge ${ }^{3}$ used ascitic fluid, similar to plasma but with less protein.

Experiments already reported ${ }^{4}$ have shown that airborne industrial flint dusts have a relatively high silica-solubility in water at $100^{\circ} \mathrm{C}$, and this solubility increases greatly as the particle-size is reduced. Under the same conditions industrial cement dusts show a much smaller solubility which varies but little with particle-size. Since flint produces silicotio lesions and cement does not, these results were accepted as supporting the general theory that dangerous dusts have a higher solubility than those which have no pathological action. Further investigation has shown that the solubility values are widely influenced by a number of additional factors. For example, the proportion of silica which dissolves

Table 1. Solubility of flint dusts in water at $100^{\circ} \mathrm{C}$. Dust : water ratio Raw flint Calcined flint

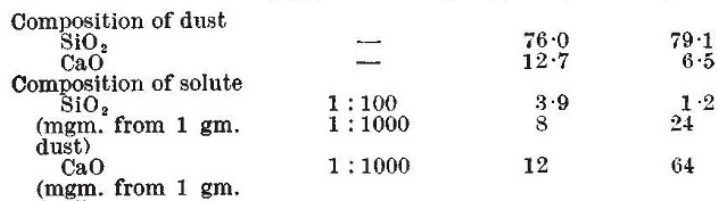

(mgm. from $1 \mathrm{gm}$. 


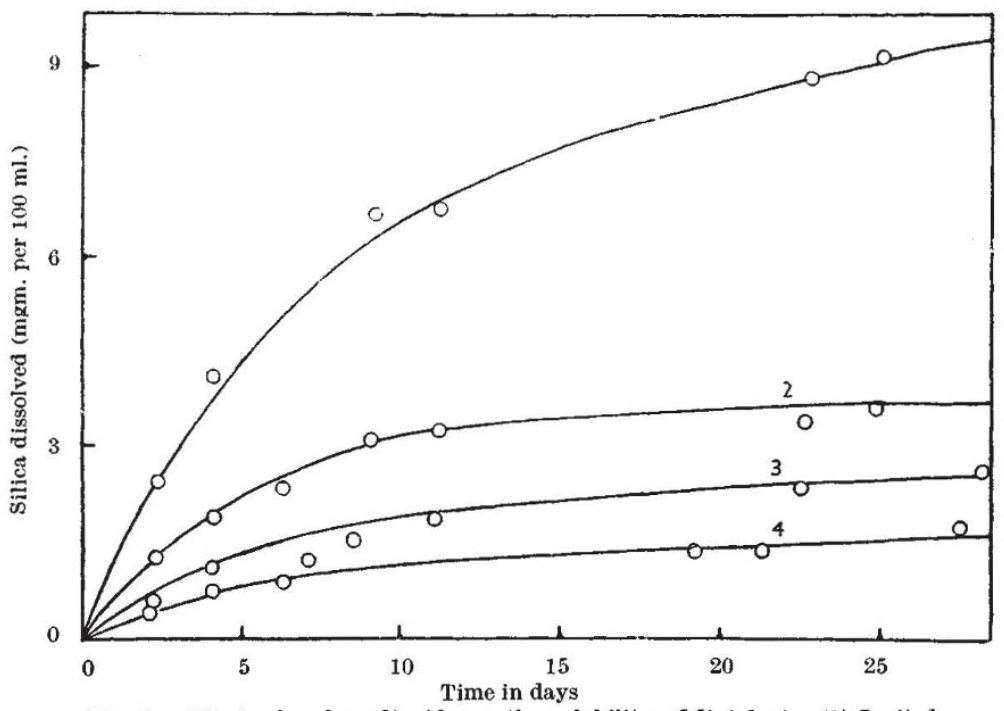

Fig. 1. Effect of carbon dioxide on the solubility of flint dust. (1) Ignited sample $+\mathrm{CO}_{2}$; (2) normal sample $+\mathrm{CO}_{2}$; (3) normal sample + air ; (4) normal sample + air free from $\mathrm{CO}_{3}$

from these industrial dusts depends markedly on the gravimetric ratio of dust to water, as is well illustrated by the figures for raw and calcined flint dusts given in Table 1 .

Carbon dioxide will also affect considerably the solubility of dusts. Calcium is present mainly as carbonate in raw flint dust, and as carbonate, silicate and sulphate in calcined flint dust. The silica solubility figures shown by the dusts in the presence of carbon dioxide may be influenced by one or more of the following factors :

(a) Caleium silicate is decomposed by carbon dioxide, resulting in an increase in the silica which passes into solution, as is shown by re-igniting a sample of calcined flint dust, thus converting much of the calcium sulphate into calcium silicate. The solubility is much increased (Fig. 1).

(b) Carbon dioxide reduces the solubility of limefree flint.

(c) Calcium carbonate increases the solubility of flint. The effects $(b)$ and $(c)$ were demonstrated by using calcined flint dust freed from calcium by washing with hot hydrochloric acid and water. Three l-gm. portions of this sample were extracted with $100 \mathrm{ml}$. of water through which air, air freed from carbon dioxide, and carbon dioxide respectively were bubbled. The solubility values given after three days are compared in Table 2 with those obtained when the original flint dust was similarly extracted. It is apparent that, whereas the original dust is considerably more soluble in the presence of carbon dioxide than in its absence, the reverse is true of the acid-treated sample. Moreover, the solubility in the absence of carbon dioxide is much greater after acid extraction. King found that the solubility of a number of dusts in Ringer solution was considerably increased after acid treatment. The addition of calcium carbonate, a substance which is present in most industrial dusts, to calcium-free flint dust increases its solubility to a maximum value in the

Table 2

$\mathrm{SiO}_{2}$ (mgm.) dissolved from $1 \mathrm{gm}$. of dust Acid-extracted dust Untreated dust presence of carbon dioxide ; further addition lowers the solubility (Table $3)$.

The curves in Fig. 2 are plotted from data obtained by following the silica-solubility of calcined flint and cement dusts when extracted with water in the presence of carbon dioxide at $18^{\circ} \mathrm{C}$. In both cases the water was replaced period. ically. The rates of solution in the first and fourth extractions are illustrated. Flint shows a progressive decline in the rate of solution with each successive ex. traction, but the opposite is true for cement. Carbon dioxide increases the silica-solubility of cement to a value comparable with that of flint, and the value is increased in subsequent extractions until it is considerably higher than that of flint.

The experiments recorded indicate that solubility values can be greatly altered by variation in the conditions of extraction. Since the composition of the dust, particularly with respect to the form and concentration of the calcium compounds it contains, largely affects the solubility, a change in composition resulting from the removal of the more soluble constituents will alter the silica-solubility values

$\begin{array}{cc}\begin{array}{c}\mathrm{CaCO}_{8} \text { added } \\ \text { Table } 3\end{array} & \begin{array}{c}\text { Dissolved } \mathrm{SiO}_{2} \\ \text { (mgm. per } 1 \text { gm. flint) }\end{array} \\ 0 & 0 \cdot 6 \\ 18 & 100 \mathrm{ml} \text {.) } \\ 93 & 4 \cdot 1 \\ 187 & 5 \cdot 9 \\ 300 & 5 \cdot 7 \\ 500 & 5 \cdot 1 \\ 1000 & 4 \cdot 3\end{array}$

during subsequent extractions. In vivo, the fluid affecting the particles is continually renewed, and possibly the solubility in vivo might be more nearly deduced from a study of the curves obtained by repeated extractions than from any single solubility

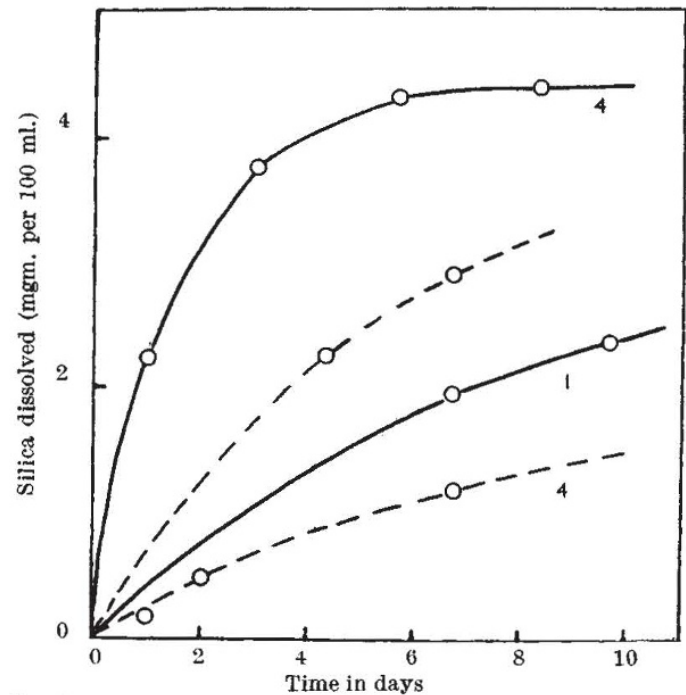

Fig. 2. Repeated extraction of flint and cement dusts by water saturated with carbon dioxide. Cuves 1, first extractions : curves 4 , fourth extractions. 
determination. Simple comparison of the solubilities of dusts using fixed conditions may give misleading results, and the correlation of solubility with pathological action by in vitro means will require a much more exhaustive study than has so far been attempted. In experiments designed to show the dissolution of dusts in the body, which will be reported elsewhere, cement has shown a relatively high solubility as compared with flint, sand (harmful dusts) and carborundum (harmless).

${ }^{1}$ Lenher, V., and Merrill, H. B., J. Amer. Chem. Soc., 39, 2630 (1917). ${ }^{2}$ Titus, A. C., J. Indust. Hyg. Toxic., 19, 138 (1937).

${ }^{3}$ King, E. J., and McGeorge, M., Biochem. J., 32, 417 (1938).

4 Briscoe, H. V. A., Matthews J. W., Holt, P. F., and Sanderson, P. M., Trans. Inst. Min. Met., 48, 270, 291 (1937).

${ }^{5}$ Whitehouse, A. G. R., J. Indust. Hyg. Toxic., 20, 556 (1938).

- Emmons, R. C., and Wilcox, R., Amer. Mineralogist, 22, 256 (1937).

${ }^{7}$ King, E. J., "Chronic Pulmonary Disease in South Wales Coal Miners, III", Med. Res. Counc. Spec. Rep. 250, p. 87 (1945).

\section{FIXATION OF FREE NITROGEN BY BARK BEETLES}

\author{
By Prof. J. PEKLO and J. SATAVA \\ Prague
}

$I^{N}$ 1912 and 1916 one of us isolated Azotobacter $(A$. Sulcii) from Afhides, ${ }^{1,2}$. More recently, L. Tóth and others ${ }^{3}$ provd by micro-Kjeldahl determinations that species of Rhynchota (Aphides, etc.) can also rapidly and considerably increase their nitrogen content by futilizing atmospheric nitrogen, though Smith $^{4}$ ha not been able to confirm these results. This year, we made more progress in studying nitrogen fixption by the bark beetle, Ips, which has done much/damage lately in Czech spruce forests.

The larvæ were mostly collected in mountain forests. Over successive intervals they were crushed with oxalacetic acid solution or similar reagent, oven-dried at $100^{\circ} \mathrm{C}$., and subjected to Kjeldahl estimations. Using large amounts $(0.5-0.8 \mathrm{gm}$.), as described by Csaky and Tóth ${ }^{5}$, did not give good results. Samples often showed a decrease in nitrogen compared with the controls. Hence, only small numbers of larvæ (30-50) were used. It was also found that results depended on the age of the larvæ. Half-grown (approximately three weeks old) larvæ fixed atmospheric nitrogen, whereas fully fed and fat ones often showed a decrease. This agrees with our view $^{6}$ that the microbial symbionts of Ips, which occur in the peripheral (so-called adipose) tissue, soon find their way into the alimentary canal, where they are digested. Pupæ and young beetles do not fix nitrogen.

Though they were often found under the bark in great quantities, it was found inadvisable to collect larvæ directly in the forest. It was best to collect large samples (10-15 kgm.) of the infested bark and to isolate the larvæ in the laboratory, grouping them according to size. Even so, it was sometimes difficult to ensure that only one species of $I p s$ was under examination, since several can occur together.

In the first series, using Ips amitinus L., from the Jizerské Mountains, in July 1948, the reagent used was either: (A) 0.088 per cent oxalacetic acid, 0.5 per cent dextrose, 0.7 per cent sodium chloride, 5.4 per cent dipotassium hydrogen phosphate; or $(B)$, which contained 0.2 per cent succinic acid in place of the oxalacetic acid and 9 per cent of phosphate. Both had $p H=7 \cdot 2$, and 3 c.c. were used with each sample of larvæ.

\begin{tabular}{|c|c|c|c|c|}
\hline Sample & $\begin{array}{c}\text { Dry weight } \\
\text { (gm.) }\end{array}$ & $\begin{array}{c}\text { Per cent } N \\
\text { in dry } \\
\text { material }\end{array}$ & $\begin{array}{l}\text { Duration of } \\
\text { fixation }\end{array}$ & $\begin{array}{l}\text { Increase } \\
\text { of } N\end{array}$ \\
\hline $\begin{array}{l}1 \\
2 \\
3 \\
4 \\
5 \\
6 \\
7 \\
8\end{array}$ & $\begin{array}{l}0 \cdot 2466 \\
0 \cdot 2480 \\
0 \cdot 2473 \\
0 \cdot 2552 \\
0 \cdot 3590 \\
0 \cdot 3727 \\
0 \cdot 3634 \\
0 \cdot 3820\end{array}$ & $\begin{array}{l}1 \cdot 7 \\
1 \cdot 92 \\
1 \cdot 81 \\
2 \cdot 08 \\
1 \cdot 52 \\
1 \cdot 46 \\
1 \cdot 61 \\
1 \cdot 57\end{array}$ & $\begin{array}{l}\text { control } \\
13 \mathrm{hr} . \\
24 \quad, \\
48 \quad, \\
\text { control } \\
13 \mathrm{hr} . \\
24 \quad, \\
48 \quad,\end{array}$ & $\begin{array}{l}13 \text { per cent } \\
6 \quad, \\
21 \quad \text { ", } \\
\text { decrease } \\
6 \text { per cent }\end{array}$ \\
\hline
\end{tabular}

Reagent $A$ was used for the first four samples, and reagent $B$ for the others. Oxalacetic acid is considered preferable to succinic acid for this work.

Further results were obtained using samples of the same species from the same locality. Small larvæ and small amounts were used, but with slightly different reagents. Reagent $C$ contained $0 \cdot 1$ per cent of aspartic acid and had a $p H=7.2$; reagent $D$ contained 0.0669 per cent of oxalacetic acid, 1 per cent dextrose and 12 per cent phosphate besides the sodium chloride; its $p \mathrm{H}=7 \cdot 7$. Reagent $E$ was the same as $A$ except for dextrose ( 1.5 per cent) and $5 \cdot 4$ per cent $\mathrm{K}_{2} \mathrm{HPO}_{4}, p \mathrm{H}=7 \cdot 0$. Reagent $F$ contained 0.132 per cent of oxalacetic acid and the higher amounts of dextrose and phosphate, $p \mathrm{H}=7 \cdot 0$.

In the following samples, reagent $C$ was used for 1 and 2 ; reagent $D$ for 3 and 4 ; reagent $E$ for 5 and 6 ; and $F$ for 7 and 8 .

\begin{tabular}{|c|c|c|c|c|}
\hline Sample & $\begin{array}{l}\text { Dry weight } \\
\text { (gm.) }\end{array}$ & $\begin{array}{c}\text { Per cent } \mathrm{N} \\
\text { in dry } \\
\text { material }\end{array}$ & $\begin{array}{l}\text { Duration of } \\
\text { flxation }\end{array}$ & $\begin{array}{l}\text { Increase } \\
\text { of } \mathrm{N}\end{array}$ \\
\hline $\begin{array}{l}1 \\
2 \\
3 \\
4 \\
5 \\
5 \\
6 \\
7 \\
8\end{array}$ & $\begin{array}{l}0 \cdot 0922 \\
0 \cdot 0923 \\
0 \cdot 0950 \\
0 \cdot 0885 \\
0 \cdot 1804 \\
0 \cdot 1798 \\
0 \cdot 3816 \\
0 \cdot 2572\end{array}$ & $\begin{array}{l}2 \cdot 89 \\
3 \cdot 19 \\
3 \cdot 46 \\
3 \cdot 64 \\
1 \cdot 78 \\
1 \cdot 84 \\
0 \cdot 84 \\
1 \cdot 33\end{array}$ & $\begin{array}{l}\text { control } \\
12 \mathrm{hr} \text {. } \\
\text { control } \\
12 \mathrm{hr} . \\
\text { control } \\
12 \mathrm{hr} . \\
\text { control } \\
12 \mathrm{hr} .\end{array}$ & 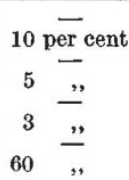 \\
\hline
\end{tabular}

A third series of tests was made with Ips typo. graphus L. and Ips (Pityogenes) chalcographus L., from Broumov Rocks (August 1948), using an oxal. acetic acid reagent.

\begin{tabular}{|c|c|c|c|c|}
\hline Sample & $\begin{array}{l}\text { Dry weight } \\
\text { (gm.) }\end{array}$ & $\begin{array}{l}\text { Per cent } N \\
\text { in dry } \\
\text { material }\end{array}$ & $\begin{array}{c}\text { Duration of } \\
\text { flxation }\end{array}$ & $\begin{array}{c}\text { Increase } \\
\text { of } N\end{array}$ \\
\hline $\begin{array}{r}1 \\
2 \\
3 \\
4 \\
5 \\
6 \\
7 \\
8 \\
9 \\
10 \\
11\end{array}$ & $\begin{array}{l}0 \cdot 1919 \\
0 \cdot 1872 \\
0 \cdot 1819 \\
0 \cdot 2016 \\
0 \cdot 2086 \\
0 \cdot 2142 \\
0 \cdot 1944 \\
0 \cdot 2024 \\
0 \cdot 1887 \\
0 \cdot 1929 \\
0 \cdot 1863\end{array}$ & $\begin{array}{l}1 \cdot 46 \\
1 \cdot 39 \\
1 \cdot 12 \\
1.59 \\
1.67 \\
1.57 \\
1.63 \\
1.28 \\
1 \cdot 11 \\
0.98 \\
1.09\end{array}$ & $\begin{array}{l}\text { control } \\
14 \mathrm{hr} . \\
24 \text {," } \\
\text { control } \\
14 \mathrm{hr} \text {. } \\
24 \quad, \\
48, \text { '” } \\
\text { control } \\
14 \mathrm{hr} . \\
\text { control } \\
14 \mathrm{hr} .\end{array}$ & $\begin{array}{c}\text { Z } \\
\text { - } \\
\text { increase } \\
\text { increase } \\
\text { - } \\
\text { increase } \\
\text { 11 per cent }\end{array}$ \\
\hline
\end{tabular}

In the first three samples, the I. typographus were very small; small to medium specimens were used in samples 4-7 and medium ones in 8 and 9 . The last two samples were young larvæ of $I$. chalcographus. In the first three samples the adipose tissue with symbionts had probably not developed, hence no nitrogen fixation. In the other samples of I. typographus the larvæ werə probably too old, hence only a small increase or decrease of nitrogen was observed. 